\title{
Immunoglobulin-Bearing and Complement-Receptor Lymphocytes Constitute the Same Population in Human Peripheral Blood
}

\author{
Alfred G. Ehlenberger, Michael McWilliams, Julia M. Phillips-Quagliata, \\ Michael E. LAMM, and Victor NuSSENZWEig \\ From the Department of Pathology, New York University School of Medicine, \\ New York 10016
}

\begin{abstract}
A B S T R A C T Complement-receptor lymphocytes have generally been considered to be a subpopulation of bonemarrow derived (B) lymphocytes. However, the present studies show that essentially all cells with integral surface immunoglobulin from normal human peripheral blood bear receptors for the third component of complement. Moreover, after removal of phagocytes, all cells with complement receptors bear surface Ig. Thus, circulating $\mathrm{B}$ cells and complement-receptor lymphocytes are the same population.
\end{abstract}

\section{INTRODUCTION}

Complement-receptor lymphocytes $(\mathrm{CRL})^{1}(1,2)$ have consistently been detected in much lower frequency than cells bearing membrane-bound immunoglobulin (Ig) in human peripheral blood. This suggests that cells bearing both Ig and complement receptors (CR) might be a subpopulation of bone-marrow derived (B) lymphocytes. However, Lobo et al. (3) and Winchester et al. (4) recently found that the percentage of human peripheral blood lymphocytes (PBL) bearing surface Ig is actually less than half that previously reported (5), the higher numbers being due to the presence of cells with passively adsorbed Ig. In the present paper, we report that if monocytes are removed from $\mathrm{PBL}$ preparations, and passively adsorbed $\mathrm{Ig}$ is eluted from the remaining

Dr. Phillips-Quagliata is a recipient of Research Career Development Award IK0 4 AI-70653 from the National Institute of Allergy and Infectious Diseases. Dr. Lamm is a Career Scientist of the Health Research Council of the City of New York under contract I-474.

Received for publication 23 June 1975 and in revised form 8 September 1975.

${ }_{1}$ Abbreviations used in this paper: A, antibody; C, complement; CR, complement receptor; CRL, complement-receptor lymphocytes; $\mathrm{E}$, erythrocytes; $\mathrm{E}_{\mathrm{T}}$, trypsin-treated sheep erythrocytes; PBL, peripheral blood lymphocytes; PBS, phosphate-buffered saline. cells by washing at $37^{\circ} \mathrm{C}$, virtually all Ig-bearing $\mathrm{PBL}$ have $C R$, and, conversely, all CRL have surface Ig. Thus, Ig-bearing lymphocytes and CRL constitute the same population in human peripheral blood and either marker can be used to identify normal, circulating $B$ lymphocytes.

\section{METHODS}

Fluoresceinated reagents. Fluoresceinated $\gamma$-globulins from goat antisera to human Ig, IgG, IgM, and IgD were purchased from Kallestad Laboratories, Inc. (Chaska, Minn.). Fluoresceinated rabbit anti- $\kappa$ and anti- $\lambda$ chain reagents were purchased from Behring Diagnostics, Somerville, N. J. Fluoresceinated rabbit antibody, specific for human $\operatorname{IgA}$ was prepared by Dr. M. E. Poger (6). The anti-IgG was specific for human IgG by double-diffusion analysis. AntiIgM was specific for the $19 \mathrm{~S}$ fraction of human serum by double-diffusion analysis, and its capacity to stain lymphocyte surfaces was abolished by absorption with soluble human $19 \mathrm{~S}$ globulin, but not by IgG. Anti-IgD was specific for IgD by Ouchterlony analysis, and its capacity to stain cell surfaces was removed by absorption with two soluble IgD myeloma proteins given to us by Dr. H. L. Spiegelberg; absorption with IgG had no effect. Anti-Ig precipitated human IgG, IgM, IgA, and IgD by double diffusion in agar gel. Its capacity to stain lymphocytes was completely removed by absorption with human IgG.

$E_{\mathrm{r}} A(I g M) C$. Preparation of sheep erythrocytes (E) coated with antibody (A) and complement (C) has been described (7). Two points should be emphasized: (a) E (Department of Health, New York) were pretreated with trypsin (Calbiochem, San Diego, Calif.) $\left(\mathrm{E}_{\mathbf{T}}\right)$ to prevent binding to human $\mathrm{T}$ lymphocytes, and $(b)$ rabbit IgM antibodies (Cordis Laboratories, Miami, Fla.) were employed to prepare $E_{T} A$, to prevent binding of $E_{T} A$ by $F c$ receptors. Controls with $E_{T}$ and $E_{T} A(\operatorname{IgM})$ formed no rosettes when incubated with human $\mathrm{PBL}$, even if centrifuged together and incubated for prolonged periods of time at $0^{\circ}, 25^{\circ}$, or $37^{\circ} \mathrm{C}$.

$E_{\mathrm{r}} A(I g M) C \cdot I g G$. These cells were prepared by treating $E_{\mathrm{T}} \mathrm{A}(\mathrm{IgM}) \mathrm{C}$ with subagglutinating doses of rabbit IgG anti-E (gift of Dr. M. Rabinovitch) sufficient to yield about $10^{3}$ molecules of $\operatorname{IgG}$ per erythrocyte. $\mathrm{E}_{\mathrm{T}} \mathrm{A}(\mathrm{IgM}) \mathrm{C}$ (without IgG) form stable rosettes with human monocytes and CRL, but are not ingested. Addition of as few as $10^{2}$ 
TABLE I

Numbers of Normal Human PBL Bearing $C R$ and Surface I $g^{*}$

\begin{tabular}{ccccc}
\hline \multirow{2}{*}{ Donor } & \multicolumn{5}{c}{ Surface markers } \\
\cline { 2 - 5 } & $\begin{array}{l}\text { Ig- } \\
\end{array}$ & Ig + & Ig- & Ig + \\
& CR + & CR + & CR- \\
\hline N. P. & 276 & 46 & 1 & 1 \\
M. G. & 277 & 41 & 1 & 1 \\
M. P. & 366 & 29 & 1 & 1 \\
Total & 919 & 116 & 3 & 3 \\
\hline
\end{tabular}

* In addition to the above observations, 14 other experiments were performed to determine which class of Ig occurs on CRL (Table II). Again, virtually no $\mathrm{Ig}+\mathrm{CR}$ - cells were observed.

molecules of IgG anti-E triggers phagocytosis by the monocytes. Because of this, phagocytosis of $E_{T} A(I g M) C \cdot I g G$ affords a very sensitive and reliable assay for human monocytes (8).

Assay for phagocytic cells. Glass-adherent cells were overlaid with saturating amounts of $E_{\mathrm{T}} \mathrm{A}(\mathrm{IgM}) \mathrm{C} \cdot \mathrm{IgG}$ and incubated at $37^{\circ} \mathrm{C}$ in a $\mathrm{CO}_{2}$ incubator for $45 \mathrm{~min}$. Nonadherent cells were suspended in RPMI 1640 medium with $N$-2-hydroxyethylpiperazine- $N^{\prime}$-2-ethane sulfonic acid buffer (Grand Island Biological Co., Grand Island, N. Y.) at $2 \times 10^{7} / \mathrm{ml}$ and equal volumes of $E_{\mathrm{T}} \mathrm{A}(\mathrm{IgM}) \mathrm{C} \cdot \mathrm{IgG}$ at $10^{\circ} / \mathrm{ml}$ were added. They were mixed by rotation $(50 \mathrm{rpm})$ at $37^{\circ} \mathrm{C}$ for $45 \mathrm{~min}$. External red cells were lysed using isotonic $\mathrm{NH}_{4} \mathrm{Cl}$. Suspended cells were deposited on slides using a cytocentrifuge, fixed, stained with MacNeal's tetrachrome strain, and examined by light microscopy for ingested erythrocytes.

$P B L$. Venous blood was drawn from normal donors into heparinized syringes and mononuclear cells were separated by flotation on Lymphoprep (Nyegaard and Co., Oslo, Norway). Mononuclear cells were harvested, washed twice at room temperature in RPMI 1640 medium, then suspended in $12 \%$ autologous serum in RPMI 1640. Approximately $5 \times 10^{7}$ mononuclear cells in a volume of $5 \mathrm{ml}$ were spread over glass slides with a total surface area of $100 \mathrm{~cm}^{2}$ and the slides were incubated at $37^{\circ} \mathrm{C}$ in a $\mathrm{CO}_{2}$ incubator for $30 \mathrm{~min}$. Nonadherent cells were removed by gently washing the slides in fresh medium. This procedure removes typical monocytes from the preparation (9). After gently rinsing the slides three times and incubating at $37^{\circ} \mathrm{C}$ for $30 \mathrm{~min}$ in fresh medium to remove passively adsorbed antibody, fewer than $1 \%$ of the adherent cells had surface Ig demonstrable by direct immunofluorescence. However, more than $99 \%$ were capable of binding heat-aggregated $\left(63^{\circ} \mathrm{C}, 20\right.$ min) IgG. Furthermore, $>98 \%$ of the cells ingested $\mathrm{E}_{\mathrm{T}} \mathrm{A}$ (IgM) C $\cdot$ IgG. After staining with tetrachrome, nearly all cells had abundant cytoplasm, and a large indented nucleus; that is, they looked like typical blood monocytes. Nonadherent lymphoid cells (PBL) were washed twice by suspending in warmed $\left(37^{\circ} \mathrm{C}\right)$ medium, incubating $5 \mathrm{~min}$, and then centrifuging at $200 \mathrm{~g}$ at room temperature. Less than $0.5 \%$ were capable of ingesting $\mathrm{E}_{\mathrm{T}} \mathrm{A}(\mathrm{IgM}) \mathrm{C} \cdot \mathrm{IgG}$ and 8$14 \%$ were positive for surface Ig using either fluoresceinated antihuman Ig or combined anti- $\kappa$ plus anti- $\lambda$ chain reagents. Approximately $6 \times 10^{7}$ mononuclear cells were obtained from $40 \mathrm{ml}$ of blood after separation on Lymphoprep, and after removal of adherent cells and washing, about $3.5 \times 10^{7}$ viable cells were recovered.
Rosettes and immunofuorescence. Lymphocytes were stained with fluorescein-conjugated antibody, and rosettes were prepared with $\mathrm{E}_{\mathrm{T}} \mathrm{A}(\mathrm{IgM}) \mathrm{C}$. Approximately $10^{7}$ nonadherent lymphocytes were suspended in $0.1 \mathrm{ml}$ of $1 \mathrm{mg} / \mathrm{ml}$ fluorescein-conjugated antibody in phosphate-buffered saline (PBS) at $\mathrm{pH} 7.4(0.15 \mathrm{M} \mathrm{NaCl}$ in $0.01 \mathrm{M}$ potassium phosphate buffer containing $0.1 \%$ sodium azide). The suspension was incubated for $30 \mathrm{~min}$ at room temperature, diluted to $1 \mathrm{ml}$ with PBS, and layered on a 1-ml cushion of fetal calf serum containing $0.1 \%$ sodium azide. The cells were centrifuged at room temperature and the cell pellet resuspended in PBS at $\mathrm{pH} 7.8 .0 .3 \mathrm{ml}$ of lymphocytes $\left(2 \times 10^{7} /\right.$ $\mathrm{ml})$ and $0.3 \mathrm{ml}$ of $\mathrm{E}_{\mathrm{T}} \mathrm{A}(\mathrm{IgM}) \mathrm{C}\left(10^{\circ} / \mathrm{ml}\right.$ in $\mathrm{PBS}$ at $\mathrm{pH}$ 7.8) were mixed in a plastic capsule (Ernest F. Fullam, Inc., Schenectady, N. Y.) with a capacity of $0.7 \mathrm{ml}$ and rotated $(50 \mathrm{rpm})$ for $30 \mathrm{~min}$ at $37^{\circ} \mathrm{C}$.

Rosettes with untrypsinized E, formed mainly by human $T$ lymphocytes, were prepared as described in (10). They were then stained as above, except that all steps were carried out at $0^{\circ}$ or $4^{\circ} \mathrm{C}$, since $\mathrm{E}$ rosettes are labile at higher temperatures.

Microscopy. Samples were examined alternately by visible and ultraviolet illumination with a Leitz Orthoplan microscope (E. Leitz, Inc., Rockleigh, N. J.) and the Ploem system of epi-illumination. Critical experiments were done in a double-blind fashion. Different observers were assigned to count rosettes and fluorescent cells, each observer tallying each field separately without knowing the results of the other observer. Then, by comparison, the extent of the overlap of the two populations was determined. A rosette was defined as a cluster composed of a lymphocyte and three or more erythrocytes.

\section{RESULTS}

In seven experiments on four normal white male donors, age 25-35 yr, PBL were stained with fluoresceinated anti-Ig, incubated with $E_{\mathrm{T}} \mathrm{A}(\operatorname{Ig} \mathrm{M}) \mathrm{C}$, and examined. Results are shown in Tables I and II. More than 97\% of cells bearing $\mathrm{CR}$ had surface Ig; conversely, more than $97 \%$ of Ig-bearing cells were also CRL. Among $\mathrm{PBL}$ as a whole, approximately $0.25 \%$ were $\mathrm{Ig}+\mathrm{CR}-$ or Ig $-\mathrm{CR}+$. It should be pointed out that Ig $-\mathrm{CR}+$ cells certainly include a few remaining monocytes since up to $0.5 \%$ of nonadherent $\mathrm{PBL}$ ingested $\mathrm{E}_{\mathrm{r}} \mathrm{A}(\operatorname{IgM}) \mathrm{C}$. IgG. Control rosettes, prepared by incubating the lymphocytes with $E$ instead of $E_{\mathrm{T}} \mathrm{A}(\mathrm{IgM}) \mathrm{C}$ to form rosettes with $T$ lymphocytes ( $E$ rosettes), were not fluorescent. As previously described (1), treatment of

TABLE II

Class of Ig on PBL Bearing $C R^{*}$

\begin{tabular}{lccc}
\hline \multirow{4}{*}{ Donor } & \multicolumn{3}{c}{ CRL stained with } \\
\cline { 2 - 4 } & anti-Ig & anti- $\mu$ & anti- $\delta$ \\
\hline & \multicolumn{3}{c}{$\%$} \\
M. M. & 100 & 80 & 78 \\
M. G. & $(100,97)$ & $(35,77)$ & 82 \\
N. P. & $(99,100)$ & 98 & 97 \\
M. P. & $(94,98)$ & $(76,80)$ & 86 \\
\hline
\end{tabular}

* Parentheses indicate experiments done on separate days. 
lymphocytes with anti-Ig did not affect the binding of $\mathrm{E}_{\mathrm{T}} \mathrm{A}(\mathrm{Ig} \mathrm{M}) \mathrm{C}$.

Experiments were also aimed at identifying the class (es) of Ig on CRL. Our observations fully confirmed the results of Lobo et al. (3) and Winchester et al. (4) that only about $1 \%$ of PBL stain with anti-r or anti- $\alpha$ reagents after removal of adherent cells and careful washing at $37^{\circ} \mathrm{C}$ to remove adsorbed Ig. Interestingly, the few $\operatorname{IgG}+$ and $\operatorname{Ig} \mathrm{A}+$ cells were found to bear CR. The great majority of CRL bear IgM and/or IgD on their membranes, although the results were variable in different individuals (Table II).

\section{DISCUSSION}

Our findings demonstrate that in normal human peripheral blood all or nearly all $B$ lymphocytes have membrane receptors for the third component of complement. After removal of phagocytes, cells which bear $\mathrm{CR}$ also display tightly bound surface Ig. Thus, tightly bound membrane Ig and the CR identify the same cell population. In the past, many investigators have reported $\mathrm{Cr}+\mathrm{Ig}$ - or $\mathrm{CR}-\mathrm{Ig}+$ cells among $\mathrm{PBL}(1,2)$. We believe that methodological pitfalls led to these results: (a) Most of the surface $\operatorname{IgG}$ and $\operatorname{IgA}$ found on human $\mathrm{PBL}$ is passively acquired $(3,4,11)$. If $\mathrm{PBL}$ are washed at $4{ }^{\circ} \mathrm{C}$ instead of $37^{\circ} \mathrm{C}$, many $\mathrm{Ig}+\mathrm{CR}$ - cells are observed, the majority bearing IgG. Removal of cytophilic antibody by washing at $37^{\circ} \mathrm{C}$ eliminates the $\mathrm{Ig}+\mathrm{CR}-$ group of cells, and also leaves few cells with detectable surface IgG. It seems unlikely that remaining Ig + cells accrue as the result of passive adsorption of fluorescent rabbit Ig; the fluoresceinated anti- $\gamma$ and anti- $\alpha$ reagents stained very few cells, and none of the fluoresceinated reagents stained monocytes under these conditions. The remaining $\mathrm{Ig}+\mathrm{CR}+$ cells for the most part bear $\operatorname{IgM}$ and/or $\operatorname{IgD}$, in agreement with the findings of Winchester et al. (4), although a few IgG + CR + or $\mathrm{IgA}+\mathrm{CR}+$ cells are also present. (b) Monocytes which contaminate PBL may appear as $\mathrm{Ig}+\mathrm{CR}+$ or Ig - CR + depending on whether cytophilic antibodies have been removed. In the present work, monocytes were removed by incubating partially purified PBL on glass slides at $37^{\circ} \mathrm{C}$ in the presence of autologous serum, a method proposed in reference 9 . This method permitted us to study the properties of both the adherent and nonadherent cells. We found that more than $98 \%$ of the glass-adherent cells were monocytes, i.e., $\mathrm{CR}+$ Ig - mononuclear cells which phagocytize EA(IgM) C. IgG. In contrast, less than $0.5 \%$ of the nonadherent cells were phagocytic. (c) Finally, if $\mathrm{E}$, instead of $\mathrm{E}_{\boldsymbol{x}}$, are used in the preparation of complement-coated cells, the $\mathrm{E}$ may bind to human $\mathrm{T}$ cells.

Our data are in agreement with the observations of Chess et al. (12) who used cell separation techniques which allowed quantitative recovery of purified populations from human PBL. They passed PBL through immunoadsorbent columns and separated $\mathrm{Ig}+$ and $\mathrm{Ig}-$ cells. All Ig + cells had CR. Among the Ig - cells, after depletion of $T$ cells by $E$ rosette formation, a minor population of nonphagocytic cells which had $\mathrm{CR}$ was isolated. However, the majority of these cells developed surface Ig by day 3 in culture. ${ }^{2}$ Furthermore, their capacity to secrete $\mathrm{Ig}$ in vitro was comparable to that of B lymphocytes. These $\mathrm{Ig}-\mathrm{CR}+$ lymphocytes also behaved similarly to isolated human $B$ lymphocytes in that they responded poorly to plant lectins, did not proliferate in response to soluble or cell-surface antigens, and were not active in cell-mediated lympholysis. In contrast, they were very efficient effector cells in antibody-dependent cellular cytotoxicity. In view of our results, it is possible that the $\mathrm{Ig}-\mathrm{CR}+$ lymphocytes of Chess et al. ${ }^{2}$ were $B$ cells which had lost their surface Ig by stripping or modulation during affinity chromatography, or that they represent B lymphocytes with little surface Ig.

The initial observations which distinguished $\mathrm{T}$ and $\mathrm{B}$ lymphocytes were followed by a large number of reports suggesting the existence of subsets of $B$ cells. These were based on the detection of three presumed B-cell surface markers: surface Ig, CR, and receptors for the Fc domain of IgG (13). Tightly bound surface Ig and Ig production have been generally assumed to be unequivocal B-cell markers. Recent evidence, however, suggests that only IgD and IgM are true B-cell markers, for only these two classes have been clearly shown to be synthesized by the cells on which they reside (14-17). These two isotypes may serve as antigen receptors which characterize virgin $B$ lymphocytes as proposed by Vitetta and Uhr (18). Among human PBL we show here that the CR is a property of virtually all cells with tightly bound Ig. The concurrent presence of these two markers on the lymphocyte membrane may imply a functional relationship in B-cell triggering. It remains to be seen whether the near absolute correspondence of these two distinct markers also holds for lymphocytes from peripheral lymphoid organs.

Finally, it is clear that large numbers of lymphocytes in peripheral blood lack $\mathrm{CR}$ and surface $\operatorname{IgM} / \operatorname{IgD}$, but bind IgG at $4^{\circ} \mathrm{C}$. Whether these cells are $\mathrm{T}$ lymphocytes, B-cell precursors, or other nondifferentiated cells remains to be determined.

'Chess, L., H. Levine, R. P. MacDermott, and S. F. Schlossman. 1975. Immunologic functions of isolated human lymphocyte subpopulations. VI. Further characterization of the surface Ig negative, EAC+, E rosette negative (null cell) subset. J. Immunol. In press. 


\section{ACKNOWLEDGMENTS}

We would like to thank Ms. Joanne Joseph for her assistance.

This work was supported in part by NIH grant numbers AI 08499, AI 09738, AI 09647, GM 000127, 5T 05GMO 1668, CA 08627, CA-14627, and by a grant from the Council for Tobacco Research-U. S. A., Inc.

\section{REFERENCES}

1. Nussenzweig, V. 1974. Receptors for immune complexes on lymphocytes. Adv. Immunol. 19: 217-258.

2. Shevach, E. M., E. S. Jaffe, and I. Green. 1973. Receptors for complement and immunoglobulin on human and animal lymphoid cells. Transplant. Rev. 16: 3-28.

3. Lobo, P. I., F. B. Westervelt, and D. A. Horwitz. 1975. Identification of two populations of immunoglobulinbearing lymphocytes in man. J. Immunol. 114: 116-119.

4. Winchester, R. J., S. M. Fu, T. Hoffman, and H. G. Kunkel. 1975. IgG on lymphocyte surfaces; technical problems and the significance of a third cell population. J. Immunol. 114 : 1210-1212.

5. N. L. Warner. 1974. Membrane immuno-globulins and antigen receptors on $\mathrm{B}$ and $\mathrm{T}$ lymphocytes. $A d v$. Immunol. 19: 67-216.

6. Poger, M. E., and M. E. Lamm. 1974. Localization of free and bound secretory component in human intestinal epithelial cells. A model for the assembly of secretory IgA. J. Exp. Med. 139: 629-642.

7. Weiner, M. S., C. Bianco, and V. Nussenzweig. 1973. Enhanced binding of neuraminidase-treated sheep erythrocytes to human T lymphocytes. Blood. 42: 939-946.

8. Ehlenberger, A. G., and V. Nussenzweig. 1975. Synergy between receptors for $\mathrm{Fc}$ and $\mathrm{C} 3$ in the induction of phagocytosis by human monocytes and neutrophils. Fed. Proc. 34 : 854. (Abstr.)
9. Koller, C. A., G. W. King, P. E. Hurtubise, A. L. Sagone, and A. F. LoBuglio. 1973. Characterization of glass-adherent human mononuclear cells. J. Immunol. 111 : 1610-1612.

10. Lay, W. H., N. F. Mendes, C. Bianco, and V. Nussenzweig. 1971. Binding of sheep red blood cells to a large population of human lymphocytes. Nature (Lond.). 230: 531-532.

11. Horwitz, D. A., and P. I. Lobo. 1975. Characterization of two populations of immunoglobulin ( $\mathrm{Ig}$ )-bearing lymphocytes in man. Fed. Proc. 34 : 1012. (Abstr.)

12. Chess, L., R. P. MacDermott, P. M. Sondel, and S. F. Schlossman. 1974. Isolation and characterization of cells involved in human cellular hypersensitivity. In Progress in Immunology II. $3: 125-132$.

13. Dickler, H. B., and H. G. Kunkel. 1972. Interaction of aggregated $\gamma$-globulin with B lymphocytes. J. Exp. Med. 1.36 : 191-196.

14. Rowe, D. S., K. Hug, L. Forni, and B. Pernis. 1973. Immunoglobulin $\mathrm{D}$ as a lymphocyte receptor. J. Exp. Med. 138: 965-972.

15. van Boxel, J. A., and D. N. Buell. 1974. IgD on cell membranes of human lymphoid cell lines with multiple immunoglobulin classes. Nature (Lond.). 251: 443-444.

16. Vitetta, E. S., and J. W. Uhr. 1975. IgD on murine lymphocytes: implications for differentiation and stimulation of lymphocytes. In Surface Membranes of Lymphocytes. M. Seligmann, editor. North-Holland Publishing Co., Amsterdam. In press.

17. Vitetta, E. S., U. Melcher, M. McWilliams, M. E. Lamm, J. M. Phillips-Quagliata, and J. W. Uhr. 1975. Cell Surface Immunoglobulin. XI. The appearance of an IgD-like molecule on murine lymphoid cells during ontogeny. J. Exp. Med. $141: 206-215$.

18. Vitetta, E. S., and J. W. Uhr. 1975. Immunoglobulin receptors revisited. Science (Wash. D. C.). 189: 964 969. 